\title{
Inhaltsverzeichnis
}

Vorwort

Preface IX

Wolfgang Detel

A New Reading of Aristotle's Philosophy of Science

Jack C. Marler

Ammonius and Eriugena: On Matter and Predication

\section{Hans Daiber}

The Limitations of Knowledge According to Ibn Sīnā :

Epistemological and Theological Aspects and the Consequences

David Wirmer

Der Begriff der Intention und seine erkenntnistheoretische Funktion

in den De-anima-Kommentaren des Averroes

Sten Ebbesen

Echoes of the Posterior Analytics in the Twelfth Century

Alexander Fidora

Dominicus Gundissalinus und die Rezeption der aristotelischen

Wissenschaftstheorie

Nadia Givsan

Zur Seelenlehre des Michael Scotus im Kontext der Wissenskultur am Hofe Friedrichs II.

Dorothée Werner

Die Selbstreflexivität der memoria bei John Blund in seinem Tractatus de anima

Steven Marrone

William of Auvergne and Aristotle on Knowing 
Jeremiah Hackett

Robert Grosseteste and Roger Bacon on the Posterior Analytics

Pia A. Antolic

„Experientia est universalis acceptio singularium“: Die Rezeption der

Zweiten Analytiken im Kommentar des Roger Bacon zu Buch I der Metaphysik

\section{Matthias Lutz-Bachmann}

Die Grundlegung des Wissens und die Rationalität der wissenschaftlichen

Erkenntnis. Zur Theorie der Wissenschaften in den Aristoteles-Kommentaren

des Thomas von Aquin

Yossef Schwartz

Die Seelenlehre des Hillel aus Verona:

Aristotelische Psychologie zwischen Maimonismus und Thomismus

Charles H. Lohr

Aristotelian "Scientia", the "Artes", and English Philosophy in the 14th Century 265

Register 275 